\title{
Interpreting elevated space-borne HCHO columns over the Mediterranean Sea using the OMI sensor
}

\author{
A. Sabolis ${ }^{1}$, N. Meskhidze ${ }^{1}$, G. Curci ${ }^{2}$, P. I. Palmer ${ }^{3}$, and B. Gantt ${ }^{1}$ \\ ${ }^{1}$ Department of Marine, Earth and Atmospheric Sciences, North Carolina State University, Raleigh, NC, USA \\ ${ }^{2}$ CETEMPS - Department of Physics, University of L'Aquila, L'Aquila, Italy \\ ${ }^{3}$ School of GeoSciences, University of Edinburgh, Edinburgh, UK
}

Received: 18 May 2011 - Published in Atmos. Chem. Phys. Discuss.: 24 June 2011

Revised: 11 November 2011 - Accepted: 2 December 2011 - Published: 16 December 2011

\begin{abstract}
Formaldehyde (HCHO) is an oxidation product of a wide range of volatile organic compounds (VOCs) and important atmospheric constituent found in both the polluted urban atmosphere and remote background sites. In this study, remotely sensed data of $\mathrm{HCHO}$ vertical column densities are analyzed over the Mediterranean Sea using the Ozone Monitoring Instrument (OMI). Data analysis indicates a marked seasonal cycle with a summer maximum and winter minimum confined to the marine environment during a three year period (2005-2007) examined. A possible retrieval artifact associated with Saharan dust transport over the region is explored by changing intensity of Saharan dust sources in GEOS-Chem following the recommendation of Generoso et al. (2008). Recalculated air mass factors (AMF), based on the new values of aerosol loadings, lead to a reduction of the summertime "hot spot" in OMI retrieval of $\mathrm{HCHO}$ vertical columns over the Mediterranean Sea; however, even after the correction, enhanced values are still present in this region. To explain these values, marine biogenic sources of VOCs are examined. Calculations indicate that emission of phytoplankton-produced isoprene is not likely to explain the enhanced HCHO vertical columns over the Mediterranean Sea. Model simulations in conjunction with measurements studies may be required to fully explore the complex mechanism of HCHO formation over the Mediterranean and its implications for the air quality in the region.
\end{abstract}

\section{Introduction}

Formaldehyde (HCHO) is one of the most abundant carbonyl compounds in both the polluted urban atmosphere and remote background sites (Ayers et al., 1997; Lee et al., 2001;

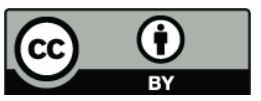

Correspondence to: N. Meskhidze (nmeskhidze@ncsu.edu)
Singh et al., 2001; Grosjean et al., 2002). Formaldehyde can be directly emitted from anthropogenic (automobile exhaust, industrial emissions, biomass burning) (Carlier et al., 1986; Sigsby et al., 1987; Andreae and Merlet, 2001) and natural sources (vegetation) (Kesselmeier and Staudt, 1999; Seco et al., 2007) or photochemically produced through the oxidation of volatile organic compounds (VOCs) (Finlayson-Pitts and Pitts, 1997; Crutzen et al., 1999). The lifetime of HCHO in the atmosphere is controlled by two main sinks: photolysis and reaction with hydroxyl radical $(\mathrm{OH})$. At low $\mathrm{OH}$ concentrations $\left(5 \times 10^{5}\right.$ molecules $\left.\mathrm{cm}^{-3}\right)$ and high $\mathrm{OH}$ concentrations $\left(1 \times 10^{7}\right.$ molecules $\left.\mathrm{cm}^{-3}\right)$, the lifetime of HCHO can be $60 \mathrm{~h}$ to $3 \mathrm{~h}$, respectively (Dufour et al., 2009). Although the photo-oxidation of methane $\left(\mathrm{CH}_{4}\right)$ is the main source of $\mathrm{HCHO}$ in the background atmosphere, the additional oxidation of non-methane VOCs (e.g., isoprene and monoterpenes) can significantly contribute to local $\mathrm{HCHO}$ concentrations (Fehsenfeld et al., 1992; Fuentes et al., 2000). Short lived VOCs with high HCHO yields (e.g., isoprene) can cause localized "hot spots" over certain regions (e.g., Southeastern United States) while the HCHO enhancement from the oxidation of longer lived VOCs will be spread over larger areas, causing a more uniform distribution. Based on this postulation, several studies have successfully used remotely sensed formaldehyde as a "top-down" approach to constrain terrestrial isoprene concentrations (Abbot et al., 2003; Palmer et al., 2003, 2006; Shim et al., 2005; Millet et al., 2008; Barkley et al., 2008; Stavrakou et al., 2009; Dufour et al., 2009; Curci et al., 2010).

Past studies focusing on VOC emissions from Europe revealed remarkably high summertime $\mathrm{HCHO}$ mixing ratios over the Mediterranean Sea, that was not well simulated by chemical transport models (Lelieveld et al., 2002; Kormann et al., 2003; Ladstätter-Weißenmayer et al., 2003, 2007; Curci et al., 2010; Klippel et al., 2011). Since HCHO has a high solubility in water, with a Henry Law constant of $\sim 6 \times 10^{3} \mathrm{~mol} \mathrm{~atm}^{-1}$ (Sander, 1999), it is generally assumed

Published by Copernicus Publications on behalf of the European Geosciences Union. 
that there are no direct emissions from the ocean (Mopper and Stahovec, 1986). Therefore, formation of formaldehyde with marine sources is most likely from the photo-oxidation of phytoplankton-produced VOCs. Previous studies have shown that considerable amounts of isoprene and, to much lesser extent, monoterpenes can be produced by marine phytoplankton (Bonsang et al., 1992; Moore et al., 1994; Shaw et al., 2003, 2010; Broadgate et al., 2004; Yassaa et al., 2008). It was proposed that incoming solar radiation and water temperature can significantly affect marine isoprene (Shaw et al., 2003; Gantt et al., 2009) and monoterpene (i.e., $\alpha$ - and $\beta$-pinene, Sabolis, 2010) emission rates, making dynamic marine areas (such as upwelling regions and estuaries) likely regions for higher marine biogenic VOC emissions compared to the global average. Although oxidation of marine VOCs can lead to the formation of HCHO, it is not clear if the rates of phytoplankton-produced VOCs are high enough to enhance HCHO signals above the background levels (determined by $\mathrm{CH}_{4}$ oxidation) and create the hot spots over marine environments large enough to be identified using remotely sensed techniques.

In this study, remotely sensed formaldehyde vertical column densities from the Ozone Monitoring Instrument (OMI) satellite sensor (Levelt et al., 2006) for the years 2005-2007 are used to explore this potential marine source of VOCs in the region of the Mediterranean Sea. Previous work illustrated that such an approach can be effective when the parent VOC has a significant HCHO yield and sufficiently short lifetime to have local relationship between the emissions of the VOC and the retrieved HCHO vertical columns (Palmer et al., 2003, 2006). Currently the origin for enhanced summertime concentrations of HCHO over the Mediterranean Sea is not clear and is suggested to be related to one or more processes such as summertime transport of continental air masses, transport of Saharan dust, intense ship traffic, and changes in surface temperature and nutrient stratification, influencing marine biota (Curci et al., 2010). This study addresses the following two questions: Does OMI consistently reveal enhanced $\mathrm{HCHO}$ vertical columns over the Mediterranean Sea? If so, is the cause due to satellite retrieval error and/or ocean biological source (i.e., oxidation of marine isoprene)?

\section{Data and methods}

\subsection{HCHO remote sensing}

Data from the OMI sensors was used in this study for the retrieval of HCHO vertical columns over the Mediterranean region. OMI is aboard NASA's EOS-Aura satellite (http:// aura.gsfc.nasa.gov/) with a sun-synchronous polar orbit and an equator crossing time of 13:38 local time. OMI has a $2600 \mathrm{~km}$ viewing swath, with pixel sizes ranging from $13 \times$ $24 \mathrm{~km}$ at nadir to $26 \times 135 \mathrm{~km}$ at the swath edges, allowing for almost daily global coverage (Millet et al., 2008). OMI is a nadir viewing UV/Vis sensor observing continuously from 270 to $500 \mathrm{~nm}$ (Kurosu et al., 2004).

Retrieval of HCHO vertical columns starts with the retrieval of slant column density ( $\mathrm{SCD}$ ), which essentially is the $\mathrm{HCHO}$ concentration integrated along the viewing path of the satellite. The retrieval algorithm for OMI HCHO SCD is based on a non-linear least-squares fitting. OMI SCDs are determined by fitting measured radiances using a spectral window between 327.5-356.5 nm (OMI-ATBD, 2002) using the GOME algorithm (Chance et al., 2000), including the Chance et al. (2005) sampling correction. Vertical columns are then calculated by dividing slant columns over a calculated Air Mass Factor (AMF). The AMF takes into account atmospheric scattering, surface albedo, satellite viewing geometry, aerosols, clouds, and the vertical distribution of HCHO. The calculation of the AMF used for conversion of a SCD into a vertical column has two parts: the use of a chemistry transport model (CTM) to generate the "shape factor" (the normalized vertical profile of $\mathrm{HCHO}$ concentration) and a radiative transfer model within the CTM to generate "scattering weights" (the vertical profile of the sensitivity of backscattered spectrum to HCHO abundance) (see Palmer et al., 2001 and Martin et al., 2002 for details). OMI data products use the GEOS-Chem global 3-D chemical transport model (Bey et al., 2001; Palmer et al., 2001; Martin et al., 2002; see Figs. S1-S2 for sample HCHO profiles and distribution) and the LIDORT radiative transfer model (Spurr et al., 2001) for the calculation of the AMF.

For OMI retrievals we use Level 2 (v003) geolocated data products (http://mirador.gsfc.nasa.gov/). Clouds in the satellite viewing scenes have been identified as the primary source of error in the retrievals (Millet et al., 2006); therefore, satellite data are gridded at a $0.25^{\circ} \times 0.25^{\circ}$ resolution with data pixels of cloud fractions $<20 \%$. The uncertainty on a single HCHO slant column is $\sim 8 \times 10^{15}$ molecules $\mathrm{cm}^{-2}$ and in relative units it ranges $40-100 \%$ (Chance and Kurosu, 2008; Curci et al., 2010), while the uncertainty on the AMF calculated with GEOS-Chem is estimated to be about $30 \%$ for cloud fractions less than 0.2 (Millet et al., 2006; Palmer et al., 2006). The total uncertainty of a single HCHO vertical column ranges from 50 to $105 \%$ (Chance and Kurosu, 2008; Curci et al., 2010). When considering regionally and temporally averaged vertical columns, the random error on the slant columns of the OMI sensor is reduced by the square root of the number of observations ( $\sim 10-30$ for monthly averages) included in the mean.

We use GEOS-Chem version 7.03 with GEOS-4 assimilated meteorological fields from the Goddard Earth Observing System (GEOS) of the NASA Global Modeling Assimilation Office regridded to a horizontal grid resolution of $2^{\circ} \times 2.5^{\circ}$ (latitude-longitude) and 47 vertical layers. In its full chemistry configuration, GEOS-Chem includes $\mathrm{H}_{2} \mathrm{SO}_{4}-$ $\mathrm{HNO}_{3}-\mathrm{NH}_{3}$ aerosol thermodynamics coupled to an $\mathrm{O}_{3}-\mathrm{NO}_{\mathrm{x}}-$ hydrocarbon-aerosol chemical mechanism (Bey et al., 2001; 


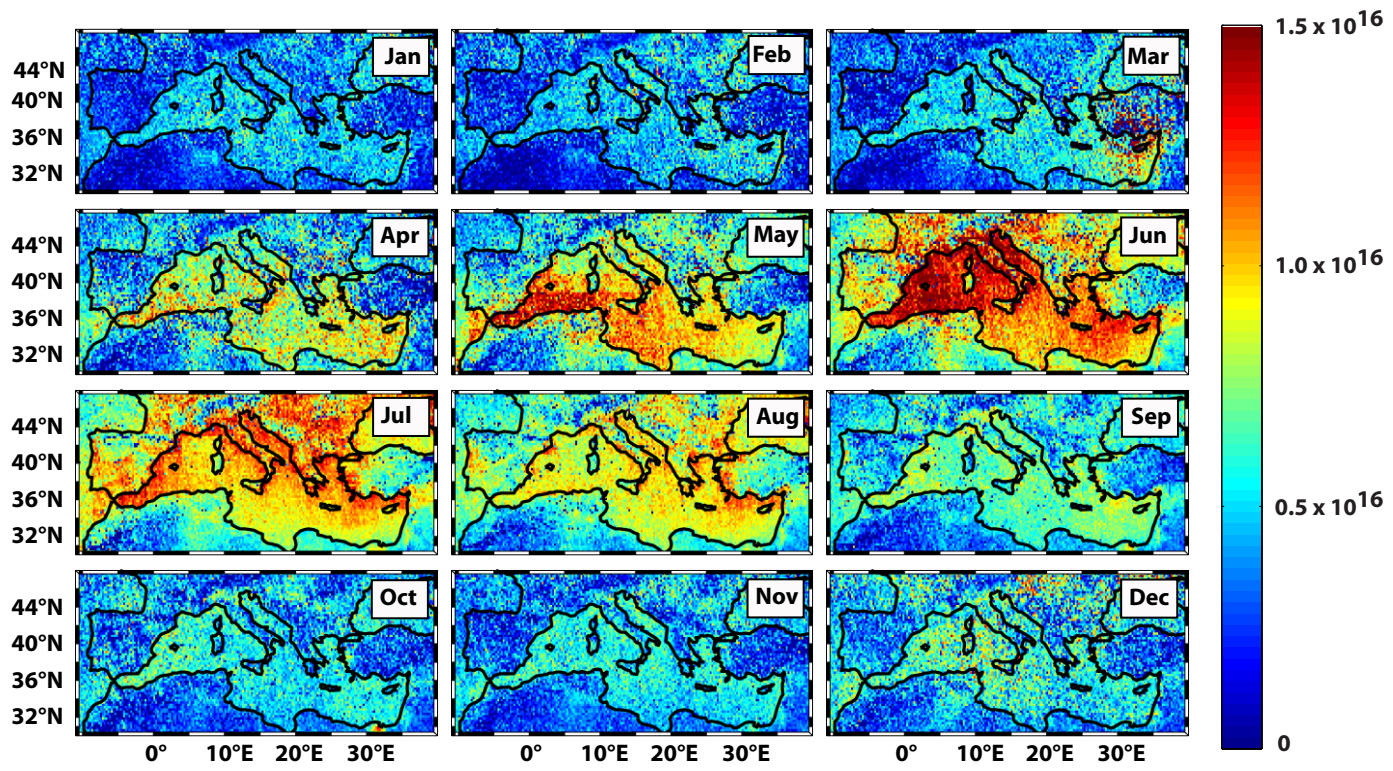

Fig. 1. Monthly averaged (from 2005 to 2007) OMI retrieved formaldehyde vertical columns in units of molecules $\mathrm{cm}^{-2}$.

Park et al., 2004). Sulfur compounds, carbonaceous aerosols, and sea-salt emission and chemistry are accounted for and described by Park et al. (2004), Heald et al. (2005), and Alexander et al. (2005).

\subsection{Biogenic sources}

It has been well documented (both in laboratory and field studies) that phytoplankton can emit several types of biogenic VOCs, including isoprene (Bonsang et al., 1992; Shaw et al., 2003, 2010; Gantt et al., 2009). Owing to its short lifetime and relatively high HCHO yield (Palmer et al., 2003, 2006), isoprene can potentially contribute to local HCHO vertical columns. It is a common practice to characterize marine emissions of isoprene by using remotely sensed surface chlorophyll- $a$ concentration ([Chl- $a]$ ) as a proxy for the phytoplankton abundance in the surface layer. However, satellite based retrievals of [Chl- $a$ ] are not sufficient to describe the phytoplankton abundance in the Mediterranean Sea. Due to strong vertical mixing, nutrients accumulate at the surface throughout the winter months. With the springtime increase in sea-water surface temperatures and incoming solar radiation, these stored nutrients can fuel biological productivity in the upper water column (Marty et al., 2002). By the summertime, the nutrients get depleted and stronglystratified oligotrophic (lacking essential nutrients to support primary productivity) surface waters can no longer sustain plankton growth. Under such conditions, phytoplankton in the Western and Eastern parts of Mediterranean Sea move lower in the water column at $\sim 50 \mathrm{~m}$ and $\sim 100 \mathrm{~m}$, respectively (Crise et al., 1999) to the depth that is usually not sampled by the satellites. Due to the seasonal formation of this deep chlorophyll maximum, satellite retrieval of [Chl- $a$ ] may not be an accurate representation of the full water column biomass. Because of such difficulties in remotely sensed [Chl- $a]$ retrievals in the Mediterranean Sea, to get an accurate representation of the biomass of marine organisms within the water column we use two satellite-based calculations of the column integrated net primary production (NPP, $\mathrm{mg} \mathrm{C} \mathrm{m}{ }^{-2} \mathrm{day}^{-1}$ ) as a proxy for a marine VOC source. One NPP calculation is the Vertically Generalized Production Model (VGPM) (Behrenfeld and Falkowski, 1997) which incorporates satellite-derived [Chl- $a$ ], sea surface temperature, cloud-corrected incident daily photosynthetically active radiation (PAR), and the day length. The other NPP calculation is the Carbon-based Productivity Model (CbPM) (Behrenfeld et al., 2005; Westberry et al., 2008) which is a function of [Chl- $a$ ], particulate backscattering coefficients, PAR, diffusion attenuation at $490 \mathrm{~nm}$ wavelength, mixed layer depth, nitrocline depth, and the day length. In comparison to satellite-derived [Chl- $a$ ], these NPP calculations are believed to be a more accurate proxy for phytoplankton biomass in oligotrophic regions. The 8-day averaged NPP products are obtained from http://www.science.oregonstate.edu/ ocean.productivity/custom.php based on input from Moderate Resolution Imaging Spectroradiometer (MODIS)-Aqua and regridded from $\frac{1}{12}^{\circ} \times \frac{1}{12}^{\circ}$ to $0.25^{\circ} \times 0.25^{\circ}$ resolution.

\section{Results}

\subsection{OMI AMF correction}

Analysis of remotely sensed data reveals that the HCHO hot spot typically appears over the Mediterranean during the warmer seasons. Figure 1 shows that during winter months, 

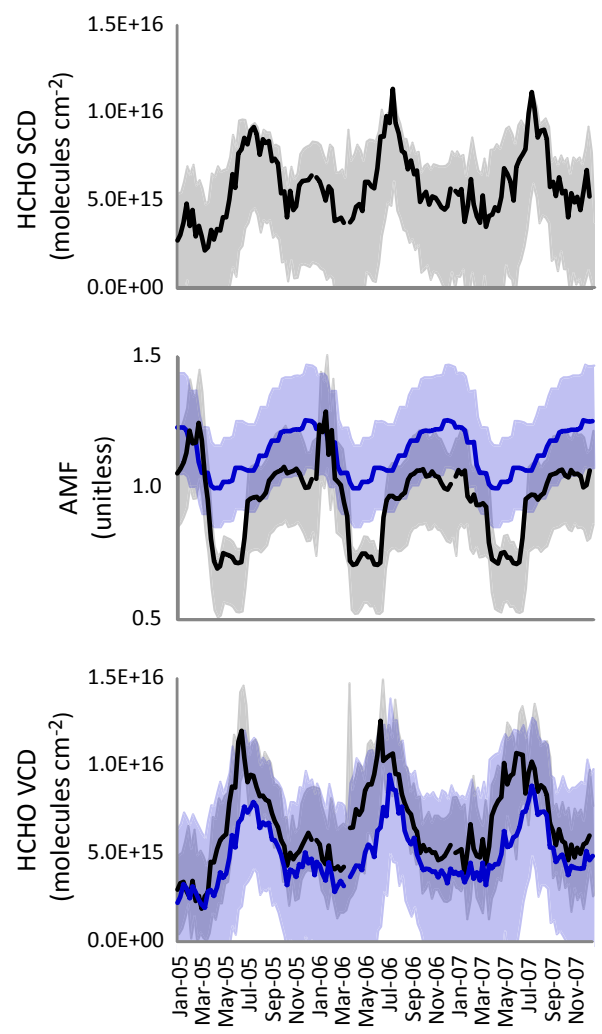

Fig. 2. Time series of 8-day averaged OMI HCHO (a) slant column density, (b) air mass factor, and (c) vertical column density from January 2005 to December 2007 for the standard (black) and corrected (blue) datasets. The data was averaged over entire Mediterranean Sea. Shaded area represents one standard error about mean observation.

the magnitude of $\mathrm{HCHO}$ vertical columns is low in all areas over the Mediterranean region $\left(\sim 3 \times 10^{15}\right.$ molecules $\left.\mathrm{cm}^{-2}\right)$. However, in late spring to summer months vertical columns are greatly enhanced over the western Mediterranean Sea. Figure 1 also shows some spatial variations: the western part of the Mediterranean displays higher summertime HCHO vertical columns compared to the eastern region. One of the possible reasons for such enhanced summertime $\mathrm{HCHO}$ vertical columns could be the presence of mineral dust in a viewing path of the satellite. Due to its proximity to the Sahara Desert, there are frequent intrusions of large dust in the Mediterranean Sea area. Although dust events are largely variable, climatological records indicate a seasonal cycle coinciding with the dry season; specifically, a maximum occurs during spring in the Eastern Mediterranean and during summer in the Western Mediterranean (Moulin et al., 1998). Moreover, persistent dust haze conditions (typically lasting 1-3 days) impact the Western Mediterranean more frequently than the eastern part (Pye, 1992). Therefore, to understand enhanced HCHO vertical columns over the Mediterranean Sea, we first examine the possible retrieval artifacts associated with Saharan dust transport over the region.
Figure 2a shows time series of 8-day averaged OMI AMF generated using GEOS-Chem and the LIDORT radiative transfer model. In this figure there is a pronounced reduction of AMFs from March to June for all three years examined. The AMF values depend on atmospheric scattering and the vertical distribution of the species. Therefore the presence of aerosols above trace gases such as HCHO in the vertical atmospheric column should lead to a strong decrease of the AMF. When satellite retrieved HCHO SCDs are divided by the reduced AMF values, higher values for vertical columns are attained (see Fig. 2b, c). However, it has recently been reported that GEOS-Chem may overestimate dust abundance for Saharan dust sources (Generoso et al., 2008). Such overestimation of Saharan dust, plumes of which often extend up to $8 \mathrm{~km}$ (Generoso et al., 2008), could cause excessive reduction in AMF values and increases in $\mathrm{HCHO}$ vertical columns. Here we have followed recommendation of Generoso et al. (2008) and reduced Saharan dust emissions by a factor of three. Figure $2 \mathrm{c}$ shows that these corrected AMF values yield considerably lower OMI HCHO vertical columns for the all three years. Figure 3 shows that corrected AMFs lead to significant reduction of the OMI retrieved HCHO vertical columns for both the western and the eastern parts of the Mediterranean Sea. Comparison of Figs. 1 and 3 shows that when the new AMF values are employed, HCHO column densities are lowered by $\sim 40 \%$ in June and by $\sim 10 \%$ in July and August. The recalculated AMFs also removed fictitious early-summertime west-east gradient associated with the excessive model dust over the Western Mediterranean. However, it should be noticed, that despite the reduction in the original $\mathrm{HCHO}$ hot spot, there is still an enhancement in the $\mathrm{HCHO}$ vertical columns confined over the water.

\subsection{Possible marine biogenic sources of HCHO over the Mediterranean Sea}

The Mediterranean is naturally oligotrophic (i.e., low nutrients and therefore low productivity), with an increase to ultraoligotrophic waters in the eastern section (Pedrós-Alió et al., 1999; Turley, 1999). However, during the winter, surface waters cool leading to a breakdown in the thermohaline circulation. This breakdown allows for vertical mixing between the deep-nutrient rich waters and the oligotrophic surface waters (Turley, 1999; Pedrós-Alió et al., 1999; Turley et al., 2000), especially in the Northwestern Mediterranean. Nutrients upwelled in winter facilitate primary production in the surface waters reaching highest levels in April, before decreasing again in summer. Figure 4 shows that the western Mediterranean has a considerable amount of productivity in the spring and summer $\left(>500 \mathrm{mg} \mathrm{C} \mathrm{m}^{-2}\right.$ day $^{-1}$ with isolated areas over $1000 \mathrm{mg} \mathrm{C} \mathrm{m}^{-2} \mathrm{day}^{-1}$ ) while the eastern Mediterranean is less productive $\left(<300 \mathrm{mg} \mathrm{C} \mathrm{m}^{-2} \mathrm{day}^{-1}\right)$. The enhancements of marine biological productivity in the Mediterranean and Atlantic Ocean (i.e., the Bay of Biscay, 

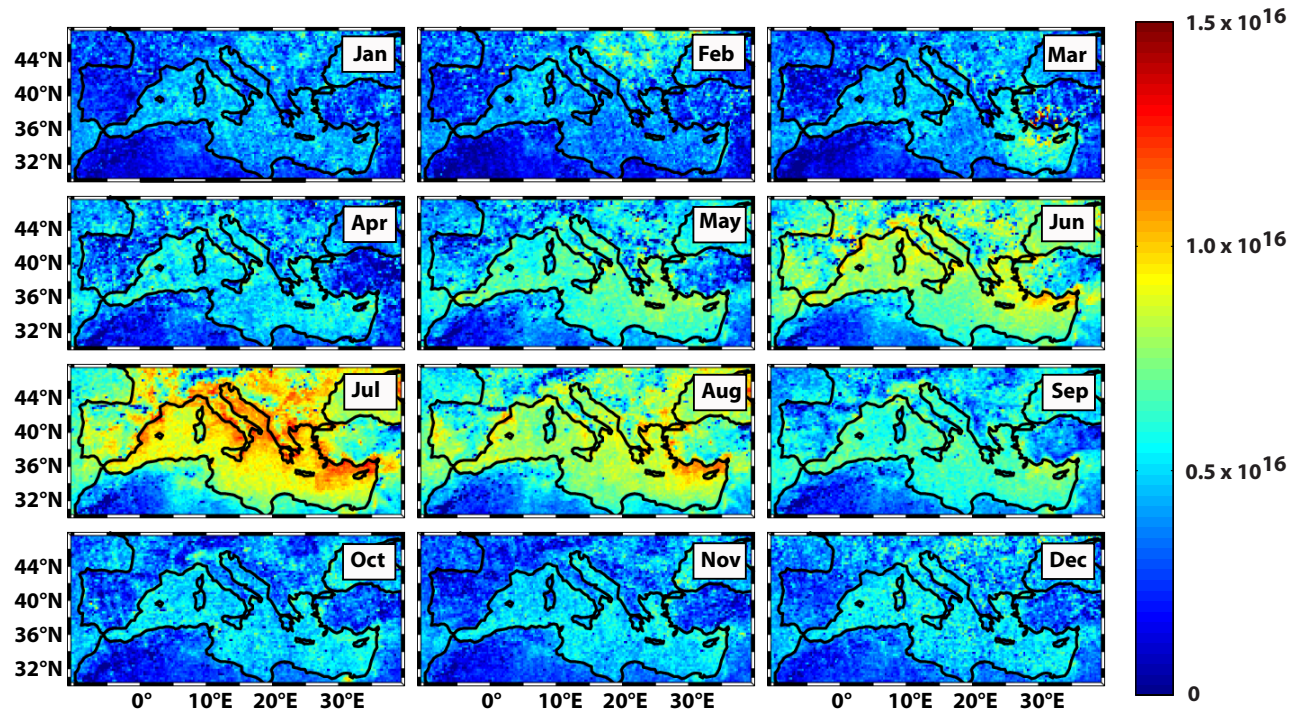

Fig. 3. Monthly averaged (from 2005 to 2007) retrieved formaldehyde vertical columns in units of molecules $\mathrm{cm}^{-2}$. The vertical columns are recalculated using corrected AMF values. See text for more details.

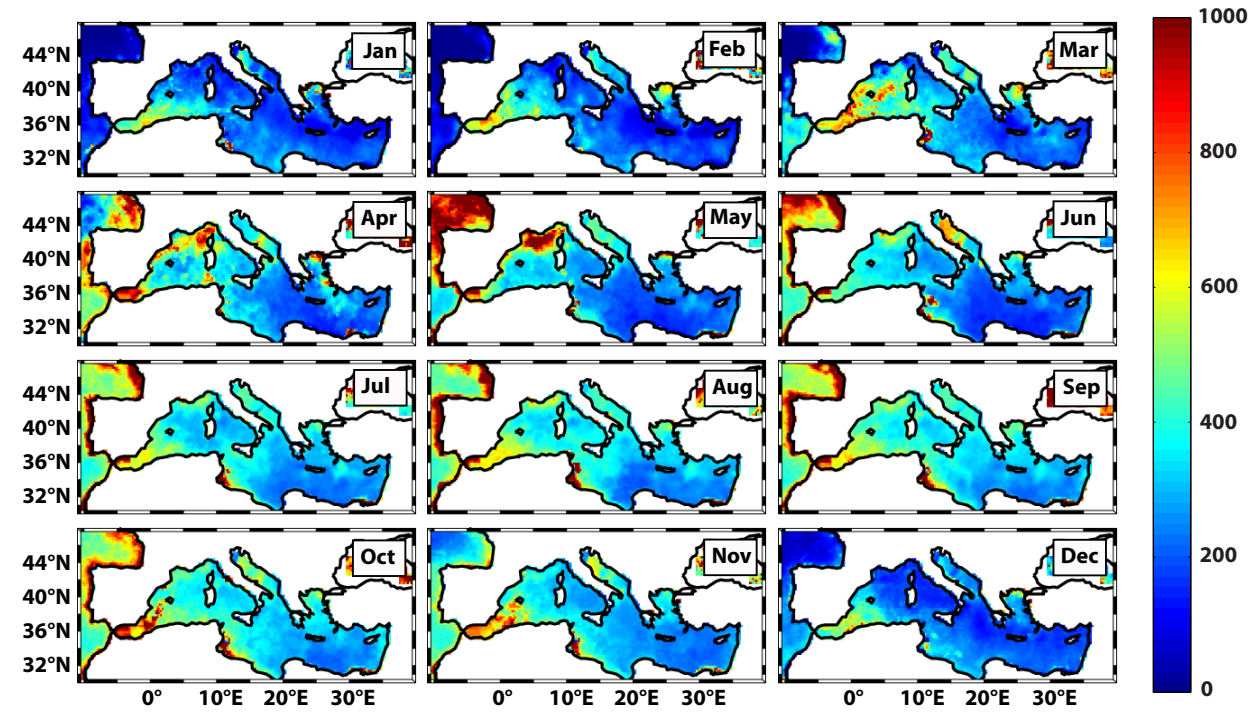

Fig. 4. Monthly averaged (from 2005 to 2007) net primary production (NPP) in units of $\mathrm{mg} \mathrm{C} \mathrm{m}^{-2}$ day $^{-1}$ from the Carbon-based Production Model (CbPM) based on input from MODIS-Aqua.

off the coast of Portugal, the coast of Italy and at the mouth of the Nile River Delta) in May are diminished by August (see Fig. 4), leading to an ultraoligotrophic environment. Comparison of Figs. 3 and 4 show that there is little similarity (either spatially or temporally) between the NPP in the Mediterranean Sea and the atmospheric column concentrations of $\mathrm{HCHO}$. In general, the areas with the highest $\mathrm{HCHO}$ vertical columns (both within the Mediterranean region and outside) do not coincide with the areas with the highest NPP. The temporal variation of the NPP and HCHO vertical columns for the Bricaud et al. (2002) sub-regions of the Mediterranean
(Fig. 5) also show little relationship between $\mathrm{HCHO}$ and NPP for all regions with the NPP typically peaking in the spring and $\mathrm{HCHO}$ vertical columns in the summer. In several subregions in the southern Mediterranean, there is little seasonal variation in the NPP while the HCHO vertical columns have a well-defined seasonal cycle. Scatterplots of the NPP and $\mathrm{HCHO}$ vertical columns for each $0.25 \times 0.25^{\circ}$ grid (Fig. 6) show little relationship between the two variables regardless of NPP calculation method and anthropogenic/terrestrial aerosol influence (using aerosol optical depth as a proxy). 


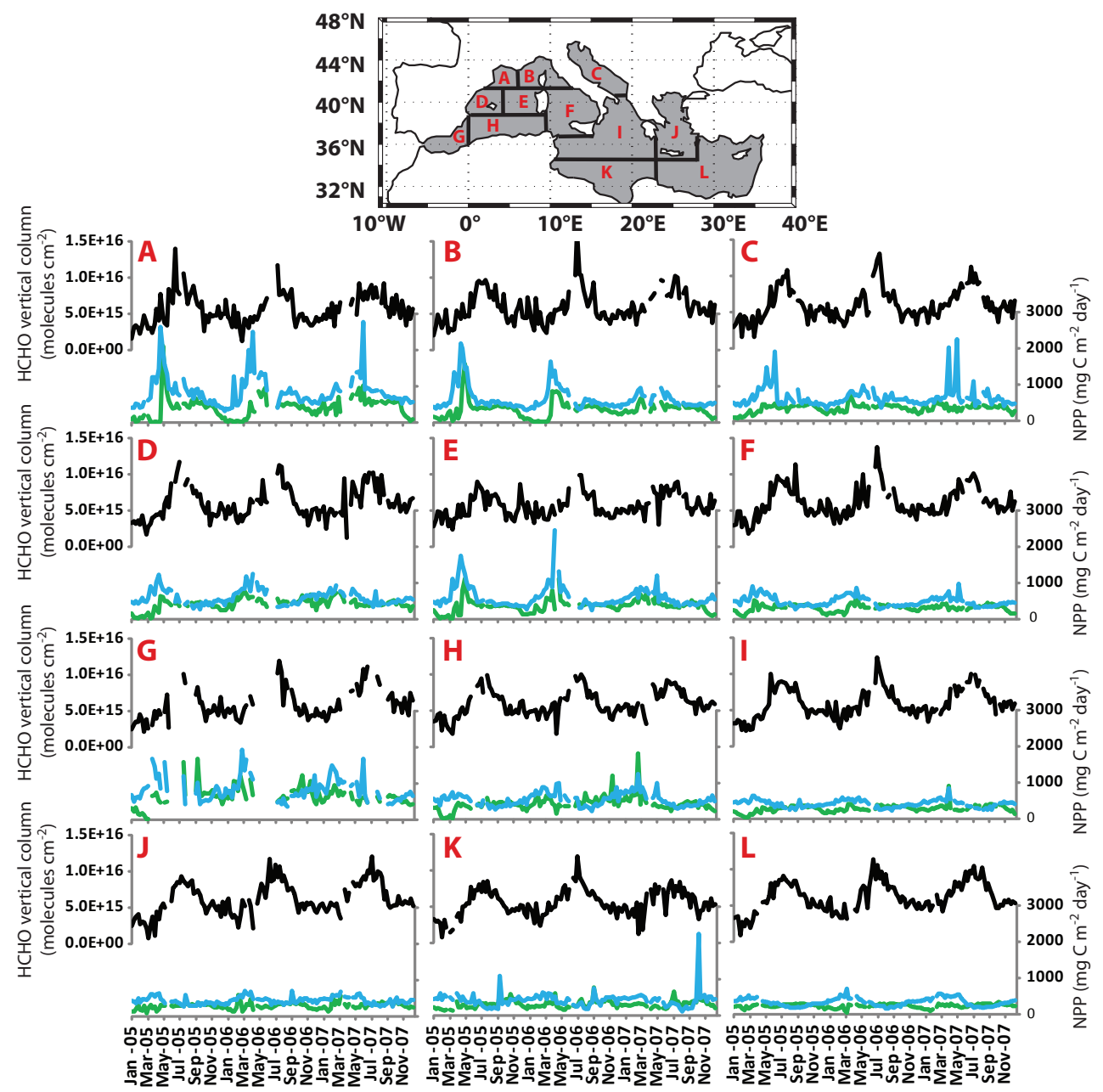

Fig. 5. Time series of 8-day averaged HCHO vertical columns from OMI (black) recalculated using corrected AMF values for January 2005 to December 2007 and the net primary productivity as estimated from the CbPM (green) and Vertically Generalized Production Model (VGPM) (blue) methods based on input from MODIS-Aqua and filtered to include only temporally and spatially collated $0.25 \times 0.25^{\circ}$ grids with 8-day averaged aerosol optical depth $(\mathrm{AOD})<0.2$ (interpolated from $1 \times 1^{\circ}$ level 3 data at $550 \mathrm{~nm}$ from the MODIS-Aqua satellite). The Bricaud et al. (2002) Mediterranean Sea subregions are the (A) Gulf of Lions, (B) Ligurian Sea, (C) Adriatic Sea, (D) Baleraric Sea, (E) Algeroprovencal Basin, (F) Tyrrhenian Sea, (G) Alboran Sea, (H) Algerian Basin, (I) North Ionian Sea, (J) Aegean Sea, (K) South Ionian Sea, and (L) Levantine Basin.

Despite the absence of clear relationship between NPP and $\mathrm{HCHO}$ vertical columns, we use the method similar to Palmer et al. (2003) and estimate the amount of ocean-derived isoprene required to explain the retrieved column concentrations of formaldehyde over the Mediterranean Sea. According to Palmer et al. (2006) HCHO yields from oxidation of pinenes are only about one third those of isoprene and have minor contribution to $\mathrm{HCHO}$ vertical columns. Assuming a background $\mathrm{HCHO}$ concentration is due to methane oxidation and longer-lived VOCs, the $\mathrm{HCHO}$ vertical columns $\left(\Omega_{\mathrm{HCHO}}\right)$ can be calculated as $\Omega_{\mathrm{HCHO}}=S \times E_{\mathrm{iso}}+B$, where $S$ is the linear slope corresponding to $\mathrm{HCHO}$ yield from isoprene $\left(1.9 \times 10^{3} \mathrm{~s}\right), E_{\text {iso }}$ is the isoprene emission rate, and $B$ is the background $\mathrm{HCHO}$ concentration (Palmer et al., 2003). The remotely sensed $\Omega_{\mathrm{HCHO}}$ can be used to back-calculate the isoprene emission necessary for the observed HCHO. Palmer et al. (2003) showed that the assumption is valid in summer at midlatitudes for a high $\mathrm{HCHO}$-yield and reactive (lifetime $30 \mathrm{~min}$ ) parent VOC (i.e., isoprene). For the background HCHO concentration we use the lowest OMI-retrieved value $(\sim 3 \times$ $10^{15}$ molecules $\mathrm{cm}^{-2}$ ) over the Mediterranean basin during the month of January. By solving the equation for $E_{\text {iso }}$ we estimate that the lowest isoprene emission required to explain the summertime maxima in the retrieved OMI HCHO vertical columns $\left(\sim 1.2 \times 10^{16}\right.$ molecules $\mathrm{cm}^{-2}$ as shown in Fig. 3 for July) is $\sim 5 \times 10^{12}$ atoms $\mathrm{C} \mathrm{cm}^{-2} \mathrm{~s}^{-1}$. This isoprene emissions rate is $\sim 2$ to 3 orders of magnitude higher than recent 


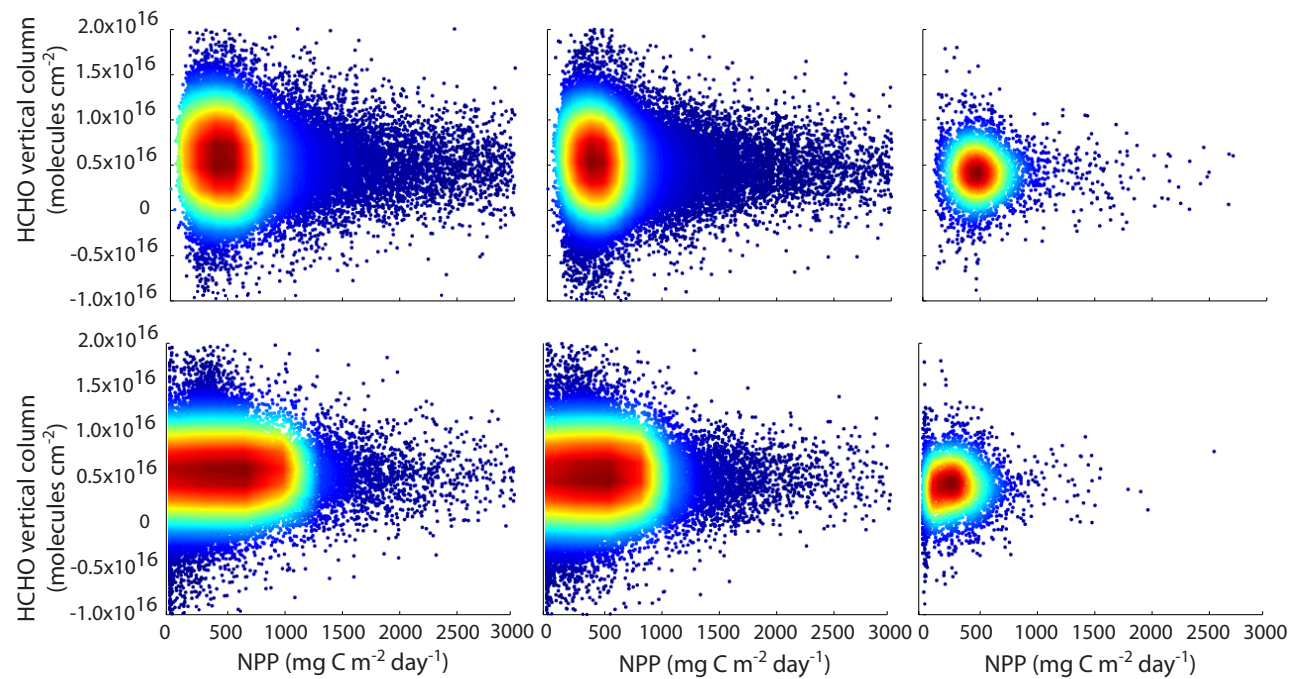

Fig. 6. Scatterplot of VGPM (top row) and CbPM (bottom row) NPP based on input from MODIS-Aqua and OMI HCHO vertical columns recalculated using updated AMF from the Mediterranean Sea subregions for $0.25 \times 0.25^{\circ}$ grids with no MODIS-Aqua AOD filter (right column), $\mathrm{AOD}<0.2$ (center column) and $\mathrm{AOD}<0.05$.

estimates of marine isoprene emissions in the Mediterranean Sea (Liakakou et al., 2007) and outside the range of uncertainty due to variability in [Chl- $a$ ] and laboratory measured isoprene emission rates (Shaw et al., 2003, 2010; Palmer and Shaw, 2005; Gantt et al., 2009; Sabolis, 2010). Although this simplified approach is in no way revealing the actual marine isoprene emissions over the Mediterranean, it does provide a rough estimate of the contribution needed in order for primary productivity to be the major source of the remotely sensed HCHO vertical columns over the Mediterranean Sea. Therefore, based on the comparison of laboratory measured isoprene emission rates and the ones estimated using remotely sensed data, we conclude that marine isoprene emissions associated with primary productivity in the Mediterranean Sea is not likely to be an important source of the retrieved summertime vertical columns of HCHO.

\subsection{Comparison with previous results}

The summertime Mediterranean basin is directly under the descending branch of the Hadley circulation, driven by deep convection in the Inter-Tropical Convergence Zone (Lelieveld et al., 2002). Owing to cloud-free conditions and higher solar radiation intensity, VOCs in the air masses transported from the surrounding regions (e.g., Central Europe, Balkans) and distant areas (e.g., Asia and North America) are subject to intense photochemical degradation. The largescale subsidence also limits upward dispersion of pollutants (Ladstätter-Weißenmayer et al., 2003), causing strongest anthropogenic influence to be detected in the lower $4 \mathrm{~km}$ over the Mediterranean basin (Lelieveld et al., 2002). Previous in situ measurements and remotely sensed data revealed remarkably high $\mathrm{HCHO}$ mixing ratios over the Mediterranean
(Lelieveld et al., 2002; Kormann et al., 2003; LadstätterWeißenmayer et al., 2003, 2007; Klippel et al., 2011). In general, reported $\mathrm{HCHO}$ concentrations were highest in the marine boundary later (up to $1500 \mathrm{ppt}$ ) and decreased with increasing altitude (Kormann et al., 2003). GOME (Global Ozone Monitoring Experiment) satellite retrieved $\mathrm{HCHO}$ vertical columns averaged over July and August, 2001 was $6.4 \times 10^{15}$ molecules $\mathrm{cm}^{-2}$, with occasional enhanced values of $1.1 \times 10^{16}$ molecules $\mathrm{cm}^{-2}$ in the Eastern Mediterranean (Ladstätter-Weißenmayer et al., 2003). Over Crete (South East Mediterranean), monthly averaged HCHO vertical columns from GOME for 1996-2002 also showed highly enhanced monthly mean summertime values between $4 \times$ $10^{15}$ and $8 \times 10^{15}$ molecules $\mathrm{cm}^{-2}$ (Ladstätter-Weißenmayer et al., 2007). Although previously reported data cannot be directly compared to the results of the current study, it shows general consistency for highly elevated summertime concentrations of HCHO over the Mediterranean basin.

The exact reasons for such enhanced $\mathrm{HCHO}$ concentrations over the Mediterranean summer conditions (factor of 4 to 5 higher compared to pacific background troposphere, Lelieveld et al. 2002) are not well understood. The model simulations consistently underestimate $\mathrm{HCHO}$ mixing ratios over the Mediterranean Sea (Ladstätter-Weißenmayer et al., 2003; Klippel et al., 2011). The discrepancy between model-predicted and measured $\mathrm{HCHO}$ concentrations over the Mediterranean region was suggested to be associated with the missing terpene chemistry (Ladstätter-Weißenmayer et al., 2003) and/or incomplete characterization of airmass trajectories (Kormann et al., 2003; Ladstätter-Weißenmayer et al., 2007; Scheeren et al., 2003). However, recent airborne campaign covering an area from the Mediterranean region in the south up to the subpolar regions north of 
Norway revealed homogeneous distribution of formaldehyde everywhere, except over the Mediterranean, where strongly elevated summertime levels of $\mathrm{HCHO}$ were reported (Klippel et al., 2011). In fact, large discrepancies between modelpredicted and measured $\mathrm{HCHO}$ concentrations over the marine boundary layer have been previously identified (Jacob et al., 1996). Although some measurement campaigns reported very low (50-250 pptv) HCHO mixing ratios over marine boundary layer, often without clear diurnal variation (Lowe and Schmidt, 1983; Mackay et al., 1996; Heikes et al., 1996), others report mixing ratios between 300 to $1000 \mathrm{ppt}$ with a distinct diurnal cycle (Zafirou et al., 1980; Arlander et al., 1990, 1995; Ayers et al., 1997; Zhou et al., 1996; Weller et al., 2000; Singh et al., 2001; Fried et al., 2002). Such high mixing ratios (factor of 2 to 4 above what is typically predicted by photochemical models considering methane $\left(\mathrm{CH}_{4}\right)$ as the only source; Logan et al., 1981), point to a possible missing HCHO source in marine boundary layer. Potential new mechanisms for the enhanced production of $\mathrm{HCHO}$ such as reaction of methylperoxy $\left(\mathrm{CH}_{3} \mathrm{O}_{2}\right)$ with hydroperoxyl radical $\left(\mathrm{HO}_{2}\right)$ (Ayers et al., 1997; Weller et al., 2000; Elrod et al., 2001) were shown not to be sufficiently important to explain measurement-model discrepancies (Fried et al., 2003). Results of our study, based on the comparison of laboratory measured ocean-isoprene emission rates and the ones estimated using remotely sensed data, suggest that contribution of ocean-derived terpenes (Ayers et al., 1997) is also not likely to be a main source of HCHO in marine boundary layer. Nevertheless, it should be noted that today very large discrepancies (factors of 30 for isoprene and 2000 for $\alpha$-pinene) exist for marine VOC emission rates estimates based on the ambient measurements and laboratory data (Luo and $\mathrm{Yu}, 2010$ ).

\section{Conclusion}

In this study, we use the Ozone Monitoring Instrument (OMI) remotely sensed formaldehyde ( $\mathrm{HCHO}$ ) vertical columns for the years 2005-2007 to explore unexpectedly high concentrations of $\mathrm{HCHO}$ observed over different parts of the Mediterranean Sea. The summertime enhancement of $\mathrm{HCHO}$ vertical columns in OMI retrievals is considerably diminished when Saharan dust emissions in GEOS-Chem are reduced by a factor of three following the recommendation of Generoso et al. (2008). The new values of aerosol loadings and the corrected air mass factors (AMFs) lead to a reduction of the summertime "hot spot" in OMI retrievals of HCHO over the Mediterranean Sea; however, even after the correction enhanced HCHO vertical columns over the Mediterranean are still present. Future studies should examine OMI HCHO vertical columns when GEOS-Chem model is driven by the Goddard Earth Observing System Model, Version 5 (GEOS-5) assimilated meteorological fields.
In addition to AMF corrections due to the presence of mineral dust over the Mediterranean Sea, possible sources associated with local photochemical production of $\mathrm{HCHO}$ are also explored. Marine biological sources of VOCs such as phytoplankton production of isoprene and monoterpenes do not seem to be probable sources for the enhanced HCHO concentrations over the Mediterranean Sea. The back-calculations show that marine isoprene emissions rates required for explaining the observed $\mathrm{HCHO}$ vertical columns are several orders of magnitude larger than previously estimated in laboratory experiments. It is unlikely that oligotrophic waters of the Mediterranean are capable of supporting such high emission rates.

This study adds further support to aircraft based measurements for elevated levels of formaldehyde over the Mediterranean Sea. Retrievals characterizing HCHO vertical columns with a defined seasonal cycle of a winter minimum and summer maximum, and large discrepancies between model-predicted and measured $\mathrm{HCHO}$ concentrations over the marine boundary layer are pointing to a possible photochemical source of HCHO over water bodies. According to this study direct production of VOCs by marine phytoplankton did not seem to be high enough to support elevated sources of HCHO; therefore we suggest future studies should examine abiotic mechanisms for formaldehyde production. Sea-water samples subjected to a natural sunlight revealed that low-molecular weight carbonyl compounds (including formaldehyde) and a whole suit of nonmethane hydrocarbons can be produced photochemically from the degradation of refractory dissolved organic matter (DOM) (Zhou and Mopper, 1997; Riemer et al., 2000). Although the net flux of formaldehyde is expected to be from air to sea, DOM has repeatedly been identified in submicron marine aerosol (O'Dowd et al., 2004; Leck and Bigg, 2005; Facchini et al., 2008; Ovadnevaite et al., 2011) photochemical aging of which can become a potential source of formaldehyde over the marine regions. Recent modeling studies show that average summertime submicron marine-source organic aerosol concentration over remote oceanic regions can be $\sim 400 \mathrm{ng} \mathrm{m}^{-3}$ (Meskhidze et al., 2011), several orders of magnitude higher than $1-2 \mathrm{ng} \mathrm{m}^{-3}$ used in previous calculations (Klippel and Warneck, 1980). Experimental studies with concurrent characterization of ambient trace gases, organic aerosol concentration and surface ocean chemical composition, supplemented by aircraft and satellite data may be required to fully explore the complex mechanism of $\mathrm{HCHO}$ formation over the Mediterranean and its implications for the air quality in the region.

\section{Supplementary material related to this article is available online at: http://www.atmos-chem-phys.net/11/12787/2011/ acp-11-12787-2011-supplement.pdf.}


Acknowledgements. This research was supported by the National Science Foundation through the grant ATM-0826117 and by the Office of Science (BER), US Department of Energy, Grant No. DEFG02-08ER64508. A. Sabolis also acknowledges support from the North Carolina Space Grant Graduate Research Fellowship. B. Gantt also receives support from the NASA Earth and Space Science (NESSF) Fellowship Program. G. Curci was supported by the Italian Space Agency in the frame of QUITSAT and PRIMES projects. P. Palmer was supported by the NERC National Centre for Earth Observation.

Edited by: M. Van Roozendael

\section{References}

Abbot, D. S., Palmer, P. I., Martin, R. V., Chance, K., Jacob, D. J., and Guenther, A.: Seasonal and interannual variability of North American isoprene emissions as determined by formaldehyde column measurements from space, Geophys. Res. Lett., 30, 1886, doi:10.1029/2003GL017336, 2003.

Alexander, B., Park, R. J., Jacob, D. J., Li, Q. B., Yantosca, R. M., Savarino, J., Lee, C. C. W., and Thiemens, M. H.: Sulfate formation in sea-salt aerosols: Constraints from oxygen isotopes, J. Geophys. Res.-Atmos., 110, 307-319, doi:10.1029/2004JD005659, 2005.

Andreae, M. O. and Merlet, P.: Emission of trace gases and aerosols from biomass burning, Global Biogeochem. Cy., 15, 955-966, 2001.

Arlander, D. W., Cronn, D. R., Farmer, J. C., Menzias, F. A., and Westberg, H. H.: Gaseous oxygenated hydrocarbons in the remote marine troposphere, J. Geophys. Res., 95, 16391-16403, 1990.

Arlander, D. W., Brüning, D., Schmidt, U., and Ehhalt, D. H.: The tropospheric distribution of formaldehyde during TROPOZ II, J. Atmos. Chem., 22, 251-268, 1995.

Ayers, G. P., Gillett, R. W., Granek, H., de Serves, C., and Cox, R. A.: Formaldehyde production in clean marine air, Geophys. Res. Lett., 24, 401-404, 1997.

Barkley, M. P., Palmer, P. I., Kuhn, U., Kesselmeier, J., Chance, K., Kurosu, T. P., Martin, R. V., Helmig, D., and Guenther, A.: Net ecosystem fluxes of isoprene over tropical South America inferred from Global Ozone Monitoring Experiment (GOME) observations of HCHO columns, J. Geophys. Res., 113, D20304, doi:10.1029/2008JD009863, 2008.

Behrenfeld, M. J. and Falkowski, P. J.: A consumer's guide to phytoplankton primary productivity models, Limnol. Oceanogr., 42, 1479-1491, 1997.

Behrenfeld, M. J., Boss, E., Siegel, D. A., and Shea, D. M.: Carbon-based ocean productivity and phytoplankton physiology from space, Global Biogeochem. Cy., 19, GB1006, doi:10.1029/2004GB002299, 2005.

Bey, I., Jacob, D. J., Yantosca, R. M., Logan, J. A., Field, B. D., Fiore, A. M., Li, Q. B., Liu, H. G. Y., Mickley, L. J., and Schultz, M. G.: Global modeling of tropospheric chemistry with assimilated meteorology: Model description and evaluation, J. Geophys. Res., 106, 23073-23095, 2001.

Bonsang, B., Polle, C., and Lambert, G.: Evidence for marine production of isoprene, Geophys. Res. Lett., 19, 1129-1132, 1992.
Bricaud, A., Bosc, E., and Antoine, D.: Algal biomass and sea surface temperature in the Mediterranean basin. Intercomparison of data from various satellite sensors, and implications for primary production estimates, Remote Sens. Environ., 81, 163178, 2002.

Broadgate, W., Malin, G., Kupper, F., Thompson, A., and Liss, P.: Isoprene and other non-methane hydrocarbons from seaweeds: a source of reactive hydrocarbons to the atmosphere, Mar. Chem., 88, 61-73, 2004.

Carlier, P., Hannachi, H., and Mouvier, G.: The chemistry of carbonyl compounds in the atmosphere, Atmos. Environ., 20, 20792099, 1986.

Chance, K. and Kurosu, T. P.: OMHCHO readme file, https://www.cfa.harvard.edu/ tkurosu/SatelliteInstruments/ OMI/PGEReleases/READMEs/OMHCHO_README.pdf, last access: June 2011, 2008.

Chance, K., Palmer, P. I., Spurr, R. J. D., Martin, R. V., Kurosu, T. P., and Jacob, D. J.: Satellite observations of formaldehyde over North America from GOME, Geophys. Res. Lett., 27, 34613464, 2000.

Chance, K., Kurosu, T. P., and Sioris, C. E.: Undersampling correction for array-detector based satellite spectrometers, Appl. Optics, 44, 1296-1304, 2005.

Crise, A., Allen, J. I., Baretta, J., Crispi, G., Mosetti, R., and Solidoro, C.: The Mediterranean pelagic ecosystem response to physical forcing, Prog. Oceanogr., 44, 219-243, 1999.

Crutzen, P. J., Lawrence, M., and Pöschl, U.: On the background photochemistry of tropospheric ozone, Tellus A, 51, 123-146, 1999.

Curci, G., Palmer, P. I., Kurosu, T. P., Chance, K., and Visconti, G.: Estimating European volatile organic compound emissions using satellite observations of formaldehyde from the Ozone Monitoring Instrument, Atmos. Chem. Phys., 10, 11501-11517, doi:10.5194/acp-10-11501-2010, 2010.

Dufour, G., Wittrock, F., Camredon, M., Beekmann, M., Richter, A., Aumont, B., and Burrows, J. P.: SCIAMACHY formaldehyde observations: constraint for isoprene emission estimates over Europe?, Atmos. Chem. Phys., 9, 1647-1664, doi:10.5194/acp-9-1647-2009, 2009.

Elrod, M. J., Ranschaert, D. L., and Schneider, N. J.: Direct kinetic study of the temperature dependence of the $\mathrm{CH}_{2} \mathrm{O}$ branching channel for the $\mathrm{CH}_{3} \mathrm{O}_{2}+\mathrm{HO}_{2}$ reaction, Int. J. Chem. Kinet., 33, 363-376, 2001.

Facchini, M. C., Rinaldi, M., Decesari, S., Carbone, C., Finessi, E., Mircea, M., Fuzzi, S., Ceburnis, D., Flanagan, R., Nilsson, E., de Leeuw, G., Martino, M., Woeltjen J., and O'Dowd, C. D.: Primary sub-micron marine aerosol dominated by insoluble organic colloids and aggregates, Geophys. Res. Lett., 35, L17814, doi:10.1029/2008GL034210, 2008.

Fehsenfeld, F., Calvert, J., Fall, R., Goldan, P., Guenther, A. B, Hewitt, C. N., Lamb, B., Liu, S., Trainer, M., Westberg, H., and Zimmermann, P.: Emissions of volatile organic compounds from vegetation and the implications for atmospheric chemistry, Global Biogeochem. Cy., 6, 389-430, 1992.

Finlayson-Pitts, B. J. and Pitts, Jr., J. N.: Tropospheric air pollution: Ozone, airborne toxics, polycyclic aromatic hydrocarbons, and particles, Science, 276, 1045-1052, 1997.

Fried, A., Lee, Y.-N., Frost, G., Wert, B., Henry, B., Drummond, J., Hübler, G., and Jobson, T.: Airborne $\mathrm{CH}_{2} \mathrm{O}$ measurements 
over the North Atlantic during the 1997 NARE campaign: Instrument comparisons and distributions, J. Geophys. Res., 107, 4039, doi:10.1029/2000JD000260, 2002.

Fried, A., Wang, Y., Cantrell, C., Wert, B., Walega, J., Ridley, B., Atlas, E., Shetter, R., Lefer, B., Coffey, M. T., Hannigan, J., Blake, D., Blake, N., Meinardi, S., Talbot, B., Dibb, J. Scheuer, E., Wingenter, O., Snow, J., Heikes, B., and Ehhalt, D.: Tunable diode laser measurements of formaldehyde during the TOPSE 2000 study: Distributions, trends and model comparisons, J. Geophys. Res., 108, 8798, doi:10.1029/2003JD003451, 2003.

Fuentes, J. D., Lerdau, M., Atkinson, R., Baldocchi, D., Bottenheim, J. W., Ciccioli, P., Lamb, B., Geron, C., Gu, L., Guenther, A., Sharkey, T. D., and Stockwell, W.: Biogenic hydrocarbons in the atmospheric boundary layer: A review, B. Am. Meteorol. Soc., 81, 1537-1575, 2000.

Gantt, B., Meskhidze, N., and Kamykowski, D.: A new physically-based quantification of marine isoprene and primary organic aerosol emissions, Atmos. Chem. Phys., 9, 4915-4927, doi:10.5194/acp-9-4915-2009, 2009.

Generoso, S., Bey, I., Labonne, M., and Breon, F. M.: Aerosol vertical distribution in dust outflow over the Atlantic: Comparisons between GEOS-Chem and Cloud-Aerosol Lidar and Infrared Pathfinder Satellite Observation (CALIPSO), J. Geophys. Res., 113, D24209, doi:10.1029/2008jd010154, 2008.

Grosjean, D., Grosjean, E., and Moreira, L. F. R.: Speciated ambient carbonyls in Rio de Janeiro, Brazil, Environ. Sci. Technol., 36, 1389-1395, 2002.

Heald, C. L., Jacob, D. J., Park, R. J., Russell, L. M., Huebert, B. J., Seinfeld, J. H., Liao, H., and Weber, R. J.: A large organic aerosol source in the free troposphere missing from current models, Geophys. Res. Lett., 32, L18809, doi:10.1029/2005GL023831, 2005.

Heikes, B., Lee, M., Jacob, D., Talbot, R., Bradshaw, J., Singh, H., Blake, D., Anderson, B., Fuelberg, H., and Thompson, A. M.: Ozone, hydroperoxides, oxides of nitrogen, and hydrocarbon budgets in the marine boundary layer over the South Atlantic, J. Geophys. Res., 101, 24221-24234, 1996.

Jacob D. J., Heikes, B. G., Fan, S.-M., Logan, J. A., Mauzerall, D. L., Bradshaw, J. D., Singh, H. B., Gregory, G. L., Talbot, R. W., Blake, D. R., and Sachse, G. W.: Origin of ozone and NOx in the tropical troposphere: A photochemical analysis of aircraft observations over the South Atlantic basin, J. Geophys. Res., 101, 24235-24250, 1996.

Kesselmeier, J. and Staudt, M.: Biogenic volatile organic compounds (VOC): An overview on emission, physiology and ecology, J. Atmos. Chem., 33, 23-88, doi:10.1023/A:1006127516791, 1999.

Klippel, W. and Warneck, P.: The formaldehyde content of the atmospheric aerosol, Atmos. Environ., 14, 809-818, 1980.

Klippel, T., Fischer, H., Bozem, H., Lawrence, M. G., Butler, T., Jöckel, P., Tost, H., Martinez, M., Harder, H., Regelin, E., Sander, R., Schiller, C. L., Stickler, A., and Lelieveld, J.: Distribution of hydrogen peroxide and formaldehyde over Central Europe during the HOOVER project, Atmos. Chem. Phys., 11, 4391-4410, doi:10.5194/acp-11-4391-2011, 2011.

Kormann, R., Fischer, H., de Reus, M., Lawrence, M., Brühl, Ch., von Kuhlmann, R., Holzinger, R., Williams, J., Lelieveld, J., Warneke, C., de Gouw, J., Heland, J., Ziereis, H., and Schlager, H.: Formaldehyde over the eastern Mediterranean during MINOS: Comparison of airborne in-situ measurements with 3D-model results, Atmos. Chem. Phys., 3, 851-861, doi:10.5194/acp-3-851-2003, 2003.

Kurosu, T. P., Chance, K., and Sioris, C. E.: Preliminary results for $\mathrm{HCHO}$ and $\mathrm{BrO}$ from the EOS-Aura Ozone Monitoring Instrument, in: Passive Optical Remove Sensing of the Atmosphere and Clouds IV, edited by: Tsay, S. C., Yokota, T., and Ahn, M.-H., Proc. of SPIE, Vol. 5652 (SPIE, Bellingham, WA, 2004), 2004.

Ladstätter-Weißenmayer, A., Heland, J., Kormann, R., von Kuhlmann, R., Lawrence, M. G., Meyer-Arnek, J., Richter, A., Wittrock, F., Ziereis, H., and Burrows, J. P.: Transport and build-up of tropospheric trace gases during the MINOS campaign: comparision of GOME, in situ aircraft measurements and MATCH-MPIC-data, Atmos. Chem. Phys., 3, 1887-1902, doi:10.5194/acp-3-1887-2003, 2003.

Ladstätter-Weißenmayer, A., Kanakidou, M., Meyer-Arnek, J., Dermitzaki, E. V., Richter, A., Vrekoussis, M., Wittrock, F., and Burrows, J. P.: Pollution events over the East Mediterranean: Synergistic use of GOME, ground-based and sonde observations and models, Atmos. Environ., 41, 7262-7273, 2007.

Leck, C. and Bigg, E. K.: Source and evolution of the marine aerosol - a new perspective, Geophys. Res. Lett., 32, L19803, doi:10.1029/2005GL023651, 2005.

Lee, S. C., Ho, K. F., Chan, L. Y., Zielinska, B., and Chow, J. C.: PAHs and carbonyl compounds in the urban atmosphere of Hong Kong, Atmos. Environ., 35, 5949-5960, 2001.

Lelieveld, J., Berresheim, H., Bormann, S., Crutzen, P. J., Dentener, F. J., Fischer, H., Feichter, J., Flateu, P. J., Heland, J., Holzinger, R., Korrmann, R., Lawrence, M. G., Levin, Z., Markowitz, K. M., Mihalopoulos, N., Minikin, A., Ramanathan, V., de Reus, M., Roelofs, G. J., Scheeren, H. A., Sclare, J., Schlager, H., Schultz, M., Siegmund, P., Steil, B., Stephanou, E. G., Stier, P., Traub, M., Warneke, C., Willians, J., and Ziereis, H.: Global air pollution crossroads over the Mediterranean, Science, 298, 794799, 2002.

Levelt, P. F., van den Oord, G. H. J., Dobber, M. R., Malkki, A., Visser, H., de Vries, J., Stammes, P., Lundell, J. O. V., and Saari, H.: The Ozone Monitoring Instrument, IEEE T. Geosci. Remote, 44, 1093-1101, 2006.

Liakakou, E., Vrekoussis, M., Bonsang, B., Donousis, Ch., Kanakidou, M., and Mihalopoulos, N.: Isoprene above the Eastern Mediterranean: Seasonal variation and contribution to the oxidation capacity of the atmosphere, Atmos. Environ., 41, 10021010, doi:10.1016/j.atmosenv.2006.09.034, 2007.

Logan, J. A., Prather, M. J., Wofsy, S. C., and McElroy, M. B.: Tropospheric chemistry: A global perspective, J. Geophys. Res., 86, 7210-7254, 1981.

Lowe, D. C. and Schmidt, U.: Formaldehyde (HCHO) measurements in the nonurban atmosphere, J. Geophys. Res., 88, 844910, 1983.

Luo, G. and Yu, F.: A numerical evaluation of global oceanic emissions of $\alpha$-pinene and isoprene, Atmos. Chem. Phys., 10, 20072015, doi:10.5194/acp-10-2007-2010, 2010.

Mackay, G. I., Karecki, D. R., and Schiff, H. I.: Tunable diode laser absorption measurements of $\mathrm{H}_{2} \mathrm{O}_{2}$ and $\mathrm{HCHO}$ during the Mauna Loa Photochemistry Experiment, J. Geophys. Res., 101, 1472114728, 1996.

Martin, R. V., Chance, K., Jacob, D. J., Kurosu, T. P., Spurr, R. J. 
D., Bucsela, E., Gleason, J. F., Palmer, P. I., Bey, I., Fiore, A., Li, Q., Yantosca, R. M., and Koelemeijer, R. B. A.: An improved retrieval of tropospheric nitrogen dioxide from GOME, J. Geophys. Res., 107, 4437, doi:10.1029/2001JD001027, 2002.

Marty, J., Chiaverini, J., Pizay, M., and Avril, B.: Seasonal and interannual dynamics of nutrients and phytoplankton pigments in the western Mediterranean Sea at the DYFAMED time-series station (1991-1999), Deep Sea Res., 49, 1965-1985, 2002.

Meskhidze, N., Xu, J., Gantt, B., Zhang, Y., Nenes, A., Ghan, S. J., Liu, X., Easter, R., and Zaveri, R.: Global distribution and climate forcing of marine organic aerosol: 1. Model improvements and evaluation, Atmos. Chem. Phys., 11, 11689-11705, doi:10.5194/acp-11-11689-2011, 2011.

Millet, D. B., Jacob, D. J., Turquety, S., Hudman, R. C., Wu, S., Fried, A., Walega, J., Heikes, B. G., Blake, D. R., Singh, H. B., Anderson, B. E., and Clarke, A. D.: Formaldehyde distribution over North America: Implications for satellite retrievals of formaldehyde columns and isoprene emission, J. Geophys. Res., 111, D24S02, doi:10.1029/2005JD006853, 2006.

Millet, D. B., Jacob, D. J., Boersma, K. F., Fu, T., Kurosu, T. P., Chance, K., Heald, C. L., and Guenther, A.: Spatial distribution of isoprene emissions from North America derived from formaldehyde column measurements by the OMI satellite sensor, J. Geophys. Res., 113, D02307, doi:10.1029/2007JD008950, 2008.

Moore, R., Oram, D., and Penkett, S.: Production of Isoprene by Marine Phytoplankton Cultures, Geophys. Res. Lett., 21, 25072510, 1994.

Mopper, K. and Stahovec, W. L.: Sources and sinks of low molecular weight organic carbonyl compounds in seawater, Mar. Chem., 19, 305-321, 1986.

Moulin, C., Lambert, E., Dayan, U., Masson, V., Ramonet, M., Bousquet, P., Legrand, M., Balkanski, Y. J., Guelle, W., Marticorena, B., Bergametti, G., and Dulac, F.: Satellite climatology of African dust transport in the Mediterranean atmosphere, J. Geophys. Res., 103, 13137-13144, 1998.

O’Dowd, C. D., Facchini, M. C., Cavalli, F., Ceburnis, D., Mircea, M., Decesari, S., Fuzzi, S., Yoon, Y. J., and Putaud, J. P.: Biogenically driven organic contribution to marine aerosol, Nature, 431, 676-680, 2004.

OMI-ATBD: (Algorithm Theoretical Basis Document), Volume IV, OMI Trace Gas Algorithms, Version 2.0, edited by: Chance, K., 2002.

Ovadnevaite, J., O’Dowd, C., Dall'Osto, M., Ceburnis, D., Worsnop, D. R., and Berresheim, H.: Detecting high contributions of primary organic matter to marine aerosol: a case study, Geophys. Res. Lett., 38, L02807, doi:10.1029/2010GL046083, 2011.

Palmer, P. I. and Shaw, S. L.: Quantifying global marine isoprene fluxes using MODIS chlorophyll observations, J. Geophys. Res., 32, L09805, doi:10.1029/2005GL022592, 2005.

Palmer, P. I., Jacob, D. J., Chance, K., Martin, R. V., Spurr, R. J. D., Kurosu, T. P., Bey, I., Yantosca, R., Fiore, A., and Li, Q.: Air mass factor formulation for spectroscopic measurements from satellites: Application to formaldehyde retrievals from the Global Ozone Monitoring Experiment, J. Geophys. Res., 106, 14539-14550, 2001.

Palmer, P. I., Jacob, D. J., Fiore, A. M., Martin, R. V., Chance, K., and Kurosu, T. P.: Mapping isoprene emissions over North
America using formaldehyde column observations from space, J. Geophys. Res., 108, 4180, doi:10.1029/2002JD002153, 2003.

Palmer, P. I., Abbot, D. S., Fu, T., Jacob, D. J., Chance, K., Kurosu, T. P., Guenther, A., Wiedinmyer, C., Stanton, J. C., Pilling, M. J., Pressley, S. N., Lamb, B., and Sumner, A. L.: Quantifying the seasonal and interannual variability of North American isoprene emissions using satellite observations of the formaldehyde column, J. Geophys. Res., 11, D12315, doi:10.1029/2005JD006689, 2006.

Park, R. J., Jacob, D. J., Field, B. D., Yantosca, R. M., and Chin, M.: Natural and transboundary pollution in?uences on sulfate-nitrateammonium aerosols in the United States: implications for policy, J. Geophys. Res., 109, D15204, doi:10.1029/2003JD004473, 2004.

Pedrós-Alió, C, Calderón-Paz, J. I., Guixa-Boixereu, N. I., Estrada, M., and Gasol, J.: Bacterioplankton and phytoplankton biomass and production during summer stratification in the northwestern Mediterranean Sea, Deep Sea Res., 46, 985-1019, 1999.

Pye, K.: Aeolian dust transport and deposition over Crete and adjacent parts of the Mediterranean Sea, Earth Surf. Proc. Land., 17, 271-288, 1992.

Riemer, D. D., Milne, P. J., Zika, R. G., and Pos, W. H.: Photoproduction of nonmethane hydrocarbons (NMHCs) in seawater, Mar. Chem., 71, 177-198, 2000.

Sabolis, A.: Quantifying marine emissions of biogenic volatile organic compounds using laboratory measurements, field measurements and remote sensing data, Master's Thesis, North Carolina State University, Raleigh, NC, http://repository.lib.ncsu. edu/ir/bitstream/1840.16/6473/1/etd.pdf, last access: 12 December 2011, 2010.

Sander, R.: Compilation of Henry's law constants for inorganic and organic species of potential importance in environmental chemistry (version 3), http://www.rolf-sander.net/henry/henry. pdf, last access: 12 December 2011, 1999.

Scheeren, H. A., Lelieveld, J., Roelofs, G. J., Williams, J., Fischer, H., de Reus, M., de Gouw, J. A., Warneke, C., Holzinger, R., Schlager, H., Klüpfel, T., Bolder, M., van der Veen, C., and Lawrence, M.: The impact of monsoon outflow from India and Southeast Asia in the upper troposphere over the eastern Mediterranean, Atmos. Chem. Phys., 3, 1589-1608, doi:10.5194/acp-31589-2003, 2003.

Seco, R., Peñuelas, J., and Filella, I.: Short-chain oxygenated VOCs: Emission and uptake by plants and atmospheric sources, sinks, and concentrations, Atmos. Environ., 41, 2477-2499, doi:10.1016/j.atmosenv.2006.11.029, 2007.

Shaw, S. L., Chisholm, S. W., and Prinn, R. G.: Isoprene production by Prochlorococcus, a marine cyanobacterium, and other phytoplankton, Mar. Chem., 80, 227-245, 2003.

Shaw, S. L., Gantt, B., and Meskhidze, N.: Marine isoprene and monoterpene production and emissions: A review, Advances in Meteorology, 2010, 408696, , 2010.

Shim, C., Wang, Y., Choi, Y., Palmer, P. I., Abbot, D. S., and Chance, K.: Constraining global isoprene emissions with Global Ozone Monitoring Experiment (GOME) formaldehyde column measurements, J. Geophys. Res., 110, D24301, doi:10.1029/2004JD005629, 2005.

Sigsby, J. E., Tejada, S., Ray, W., Lang, M., and Duncan, J. W.: Volatile organic compounds emissions from 46 in-use passenger cars, Environ. Sci. Technol., 21, 466-475, 1987. 
Singh, H., Chen, Y., Staudt, A., Jacob, D., Blake, D., Heikes, B., and Snow, J.: Evidence from the Pacific troposphere for large global sources of oxygenated organic compounds, Nature, 410, 1078-1081, 2001.

Spurr, R. J. D., Kurosu, T. P., and Chance, K. V.: A linearized discrete ordinate radiative transfer model for atmospheric remote sensing retrieval, J. Quant. Spectrosc. Radiat. Transfer, 68, 689735,2001

Stavrakou, T., Müller, J.-F., De Smedt, I., Van Roozendael, M., van der Werf, G. R., Giglio, L., and Guenther, A.: Global emissions of non-methane hydrocarbons deduced from SCIAMACHY formaldehyde columns through 2003-2006, Atmos. Chem. Phys., 9, 3663-3679, doi:10.5194/acp-9-3663-2009, 2009.

Turley, C.: The changing Mediterranean Sea - a sensitive Ecosystem?, Prog. Oceanogr., 44, 387-400, 1999.

Turley, C. M., Bianchi, M., Christaki, U., Conan, P. Harris, J. R. W., Psarra, S., Ruddy, G., Stutt, E. D., Tselepides, A., and van Wambeke, F.: Relationship between primary producers and bacteria in an oligotrophic sea - the Mediterranean and biogeochemical implications, Mar. Ecol.-Prog. Ser., 193, 11-18, 2000.

Weller, R. O., Schrems, O., Boddenberg, A., Gäb, S., and Gautrois, M.: Meridional distribution of hydroperoxides and formaldehyde in the marine boundary layer of the Atlantic $\left(48^{\circ} \mathrm{N}-35^{\circ} \mathrm{S}\right)$ measured during the Albatross campaign, J. Geophys. Res., 105, 14401-14412, 2000.
Westberry, T., Behrenfeld, M. J., Siegel, D. A., and Boss, E.: Carbon-based primary productivity modeling with vertically resolved photoacclimation, Global Biogeochem. Cy., 22, GB2024, doi:10.1029/2007GB003078, 2008.

Yassaa, N., Peeken, I., Zöllner, E., Bluhm, K., Arnold, S., Spracklen, D., and Williams, J.: Evidence for marine production of monoterpenes, Environ. Chem., 5, 391-401, doi:10.1071/EN08047, 2008.

Zafirou, O. C., Alford, J., Herrera, M., Peltzer, E. T., Gagosian, R. B., and Liu, S. C.: Formaldehyde in remote marine air and rain: Flux measurements and estimates, Geophys. Res. Lett., 7, 341344, 1980.

Zhou, X. and Mopper, K.: Photochemical production of low molecular weight carbonyl compounds in seawater and surface microlayer and their air-sea exchange, Mar. Chem., 56, 201-214, 1997.

Zhou, X., Lee, Y.-N., Newman, L., Chen, X., and Mopper, K.: Tropospheric formaldehyde concentration at the Mauna Loa Observatory during the Mauna Loa Photochemistry Experiment 2, J. Geophys. Res., 101, 14711-14719, 1996. 